\title{
Musim Hujan sebagai Faktor Risiko Kambuh pada Anak Penderita Sindrom Nefrotik Sensitif Steroid
}

\author{
Arief Budiman, ${ }^{1}$ Dany Hilmanto, ${ }^{2}$ Herry Garna ${ }^{2}$ \\ ${ }^{1}$ Bagian Ilmu Kesehatan Anak Rumah Sakit Umum Daerah Banjar \\ ${ }^{2}$ Departemen Ilmu Kesehatan Anak Fakultas Kedokteran Universitas Padjadjaran- \\ Rumah Sakit Dr. Hasan Sadikin, Bandung
}

\begin{abstract}
Abstrak
Kekambuhan pada sindrom nefrotik sensitif steroid (SNSS) cukup sering terjadi. Faktor risiko kambuh antara lain adalah usia serangan pertama, atopi, infeksi saluran pernapasan akut (ISPA) karena virus, dan genetik. Mekanisme kambuh juga berkaitan dengan pelepasan interleukin yang dapat dicetuskan oleh kelembaban tinggi dan suhu rendah seperti yang terjadi pada musim hujan. Penelitian ini bertujuan untuk mengetahui apakah musim hujan dapat merupakan faktor risiko kambuh pada anak penderita SNSS. Penelitian dengan rancangan kohort prospektif ini dilakukan selama periode Oktober 2005-September 2006 di Departemen Ilmu Kesehatan Anak RS Dr. Hasan Sadikin Bandung dengan subjek penelitian penderita SNSS kambuh, berusia 1-14 tahun. Dilakukan wawancara serta dicatat waktu kambuh pada musim hujan (Oktober 2005-Maret 2006) dan kemarau (April-September 2006). Kriteria kambuh berdasarkan International Study of Kidney Disease in Children (ISKDC). Analisis statistik menggunakan uji perubahan McNemar. Faktor risiko kambuh ISPA dan riwayat atopi diuji dengan analisis multivariabel regresi logistik. Besar sampel berdasarkan rumus data berpasangan diperoleh sebesar 35. Terdapat 43 subjek terdiri atas 26 laki-laki dan 17 perempuan. Sebanyak 26 subjek kambuh pada musim hujan dan 7 subjek kambuh pada musim kemarau $\left(\mathrm{X}^{2}=9,818 ; \mathrm{p}=0,002 ; \mathrm{RR}=3,71 ; 95 \%\right.$ IK 2,6-9,8). Analisis multivariabel dengan regresi logistik yang mengikutsertakan faktor ISPA dan riwayat atopi tidak menunjukkan perbedaan kejadian kambuh pada musim hujan dan kemarau $(p>0,05)$. Disimpulkan bahwa musim hujan merupakan faktor risiko terjadinya kambuh pada anak yang menderita SNSS. [MKB. 2011;43(3):112-6].
\end{abstract}

Kata kunci: Kambuh, musim hujan, sindrom nefrotik sensitif steroid

\section{Rainy Season as the Risk Factor of Relapse in Children with Steroid Sensitive Nephrotic Syndrome}

\begin{abstract}
Relapse were common in children with steroid-sensitive nephrotic syndrome (SSNS). Risks of relapse were age at onset, atopic history, acute viral respiratory tract infection (ARI), and genetic. Releasing of interleukin is associated with relapse mechanism in nephrotic syndrome and may be precipitated by high humidity and low temperature as in rainy season. The aim of this study was to determine rainy season as the risk factor of relapse in SSNS. Other risk factors such as ARI and atopic history were also included. This cohort prospective study was conducted of relapsing SSNS patients who fulfilled the criteria of International Study of Kidney Diseases in Children (ISKDC), aged 1-14 years. We recorded time of relapse in rainy season (October 2005-March 2006) and dry season (April-September 2006). Statistical analysis by McNemar and for ARI and atopic history by logistic multivariable regression. From statistical calculation minimal samples were 35. A total of 43 subjects (26 boys and 17 girls) fulfilled the inclusions criteria. Of these subjects, 26 relapsed in rainy season and 7 in dry seasons $\left(X^{2}=9.818, p=0.002, R R=3.71,95 \%\right.$ CI 2.6-9.8). Multivariable analysis with logistic regression revealed that ARI and atopic history had no association with relapses in both seasons $(\mathrm{p}>0.05)$. We conclude that rainy season is the risk factor for relapse of SSNS. [MKB. 2011;43(3):112-6].
\end{abstract}

Key words: Rainy season, relapse, steroid-sensitive nephrotic syndrome

Korespondensi: Arief Budiman, dr., Sp.A., M.Kes Bagian Ilmu Kesehatan Anak Rumah Sakit Umum Daerah Banjar, jalan Rumah Sakit 5 Banjar, telepon (0265) 744242, mobile 08122024367, e-mail: mysonalqy@yahoo.com 


\section{Pendahuluan}

Sindrom nefrotik (SN) hingga saat ini masih merupakan penyebab utama rujukan kepada dokter nefrologi anak karena kronisitas serta kompleksnya evaluasi dan penanganan penyakit tersebut. Insidensi SN pada anak berusia di bawah 16 tahun sebanyak 2-7 kasus per 100.000 orang per tahun. ${ }^{1}$ Insidensi SN di Indonesia diperkirakan 6 kasus per tahun tiap 100.000 anak usia kurang dari 14 tahun. ${ }^{2}$ Penelitian $\mathrm{Hafni}^{3}$ di Departemen Ilmu Kesehatan Anak FKUP/Rumah Sakit Dr. Hasan Sadikin Bandung tahun 20002004 menunjukkan angka kejadian SN kambuh sebanyak 123 kasus (periode Oktober-Maret dan periode April-September masing-masing sebanyak 73 dan 50 kasus).

Berdasarkan etiologinya, SN dibagi atas SN primer yang sebagian besar berbentuk idiopatik (90\%) dan SN sekunder. ${ }^{1,4}$ Sekitar $75-80 \%$ SN idiopatik secara histopatologis menunjukkan kelainan minimal dan lebih dari 95\% memberikan respons yang baik terhadap pengobatan steroid. ${ }^{5}$ Meskipun demikian, sekitar 60-80\% penderita akan mengalami kambuh. ${ }^{6}$ Kejadian kambuh secara berulang-ulang pada anak penderita SN idiopatik ini perlu dicegah, karena akan memperburuk prognosis penderita akibat toksisitas steroid dan kemungkinan terjadi perubahan kelainan histopatologis menjadi nonminimal (glomerulosklerosis). ${ }^{7}$

Berbagai faktor telah diteliti dan dianggap merupakan risiko untuk terjadinya kambuh pada penderita sindrom nefrotik sensitif steroid (SNSS), yaitu riwayat atopi ${ }^{8}$ jenis human leucocyte antigen (HLA) tertentu, ${ }^{9}$ usia saat serangan pertama, ${ }^{10}$ dan infeksi saluran pernapasan akut (ISPA) bagian atas oleh virus yang menyertai atau mendahului terjadinya kambuh. ${ }^{11}$

Kambuh pada SN ditandai dengan terjadinya proteinuria setelah mengalami remisi. ${ }^{7}$ Mekanisme proteinuria yang merupakan gejala utama terjadinya kambuh pada penderita SN belum diketahui dengan pasti, tetapi diduga melibatkan pelepasan berbagai jenis sitokin, terutama interleukin (IL-4 dan IL13)..$^{12,13}$

Suhu rendah dan kelembaban tinggi seperti pada musim hujan di Indonesia dapat mencetuskan reaksi hipersensitivitas tipe nonalergik yang mengakibatkan pelepasan berbagai sitokin oleh sel mast dan basofil. ${ }^{14}$ Melalui mekanisme tersebut, keadaan musim hujan ini mungkin berkaitan dengan timbulnya proteinuria pada anak yang menderita SNSS dan mengakibatkan terjadinya kambuh.

Penelitian ini bertujuan untuk mengetahui apakah musim hujan dapat merupakan faktor risiko kambuh pada anak penderita SNSS.

\section{Metode}

Penelitian epidemiologi klinik dengan rancangan kohort prospektif ini dilakukan selama bulan Oktober 2005-September 2006 di Departemen Ilmu Kesehatan Anak RS Dr. Hasan Sadikin Bandung dengan subjek penelitian adalah penderita SNSS kambuh. Kriteria inklusi pada penelitian ini adalah: (1) usia anak 1-14 tahun, (2) tergolong $\mathrm{SN}$ idiopatik yang memberikan respons baik terhadap pengobatan steroid, (3) berdomisili di Jawa Barat. Kriteria eksklusi adalah penderita SN sekunder, yaitu SN yang etiologinya berasal dari luar ginjal atau penyakit sistemik. Definisi kambuh menurut kriteria International Study of Kidney Diseases in Children (ISKDC) adalah terjadinya kembali proteinuria $>40 \mathrm{mg} / \mathrm{jam} / \mathrm{m}^{2}$ atau albustix ++ atau lebih, selama 3 hari berturutturut pada penderita $\mathrm{SN}$ setelah mengalami remisi. ${ }^{5}$ Dilakukan wawancara serta dicatat waktu kambuh pada musim hujan (Oktober 2005-Maret 2006) dan kemarau (April-September 2006). Periode musim ini didasarkan pada data Badan Meteorologi dan Geofisika Bandung 2006. ${ }^{15}$

Pada penelitian ini dilihat hubungan tiga variabel bebas (infeksi saluran pernapasan akut bagian atas, riwayat atopi, dan pola musim) dengan variabel terikat (SN kambuh). Untuk mencari hubungan antara variabel bebas, yaitu musim hujan atau kemarau dan variabel tergantung, yaitu kambuh dilakukan analisis statistik dengan uji perubahan Mc Nemar, sedangkan untuk menilai besarnya risiko musim hujan atau kemarau terhadap kejadian kambuh digunakan nilai risiko relatif (RR) menggunakan interval kepercayaan (IK) 95\%. Untuk menguji berbagai faktor risiko secara bersama-sama digunakan analisis multivariabel regresi logistik. Berdasarkan rumus statistik untuk data berpasangan besar sampel diperoleh sebanyak 35 .

\section{Hasil}

Selama periode penelitian didapatkan 43 subjek terdiri atas 26 anak laki-laki dan 17 anak perempuan. Karakteristik umum subjek penelitian meliputi jenis kelamin, usia saat penelitian, dan usia saat serangan pertama dapat dilihat pada Tabel 1.

Analisis lebih lanjut mengenai kekambuhan yang terjadi pada musim hujan dan kemarau dengan menggunakan tabel $2 \times 2$ dapat dilihat pada Tabel 2 .

Tabel 2 menunjukkan sebanyak 26 subjek yang mengalami kambuh pada musim hujan dan 7 subjek mengalami kambuh pada musim kemarau. Hasil statistik menunjukkan besarnya risiko relatif $\mathrm{RR}=3,71$; artinya seorang penderita 
Tabel 1 Karakteristik Umum Subjek Penelitian

\begin{tabular}{cc}
\hline \multicolumn{1}{c}{ Karakteristik } & Jumlah \\
\hline Jenis kelamin & 26 \\
Laki-laki & 17 \\
Perempuan & 83 \\
Usia (bulan) & $16-156$ \\
Rata-rata & \\
Rentang & 66 \\
Usia saat serangan pertama SN (bulan) & $12-150$ \\
Rata-rata & \\
Rentang &
\end{tabular}

Tabel 2 Tabulasi Silang Kejadian Kambuh pada Musim Hujan dan Kemarau Penderita SNSS

\begin{tabular}{cccccc}
\hline & \multirow{2}{*}{ Musim } & & \multicolumn{2}{c}{ Kekambuhan } & \multirow{2}{*}{ Total } \\
\cline { 3 - 5 } & & $(+)$ & $(-)$ & 36 \\
Hemarau & & $(-)$ & 7 & 10 & 7 \\
\hline
\end{tabular}

Keterangan: $(+)=$ Kambuh; $(-)=$ Tidak Kambuh

Uji kemaknaan McNemar menghasilkan $x^{2}=9,818 ; p=0,002 ; R R=3,71$ (95\% IK 2,6-9,8)

SNSS mempunyai risiko sebesar 3,71 kali untuk mengalami kambuh pada musim hujan dibandingkan dengan musim kemarau.

Stelah dilakukan analisis univariabel terhadap riwayat ISPA dan atopi pada kedua musim ternyata nilai kemaknaan $p<0,25$. Hasil yang didapatkan pada kelompok dengan riwayat ISPA dan nonISPA serta nonatopi, nilai $\mathrm{p}$ ketiganya di bawah 0,25 kecuali pada kelompok dengan atopi $(p=1,0)$. Berdasarkan analisis di atas, peneliti melakukan analisis multivariabel antara riwayat ISPA dan atopi terhadap kedua musim.

Analisis multivariabel dengan regresi logistik yang mengikut sertakan faktor ISPA dan riwayat atopi tidak menunjukkan perbedaan kejadian kambuh, baik pada musim hujan ataupun kemarau $(\mathrm{p}>0,05)$ (Tabel 3).

\section{Pembahasan}

Sindrom nefrotik sensitif steroid adalah penyakit multifaktorial melibatkan komponen imunologis dan lingkungan. Dari berbagai temuan klinis serta laboratorium terdapat hubungan antara SN dan kelainan imunologis. Meskipun demikian, peranan kelainan imunologis terhadap sindrom nefrotik terutama yang mengalami kambuh belum jelas. ${ }^{16}$

Hasil penelitian menunjukkan ada hubungan antara pola musim dan kekambuhan SNSS. Mekanisme yang menerangkan kambuh pada penderita SNSS dapat dijelaskan dengan teori berikut ini: suhu rendah dan kelembaban tinggi seperti pada musim hujan menimbulkan reaksi hipersensitivitas nonalergi melalui peningkatan

Tabel 3 Analisis Multivariabel Hubungan ISPA dan Atopi dengan Kejadian Kambuh pada Musim Kemarau

\begin{tabular}{lcccc}
\hline \multicolumn{1}{c}{ Variabel } & Koefisien $\boldsymbol{\beta}$ & SE $(\boldsymbol{\beta})$ & Nilai p & OR (95\% IK ) \\
\hline ISPA & $-0,606$ & 0,712 & 0,395 & $0,545(95 \%$ IK $=0,135-2,204)$ \\
Atopi & 1,609 & 1,360 & 0,237 & $5,0 \quad(95 \%$ IK $=0,348-71,9)$ \\
Konstanta & $-0,310$ & - & - & - \\
\hline Akurasi: $62,8 \%$ & & &
\end{tabular}

Tabel 4 Hubungan ISPA dan Atopi dengan Kejadian Kambuh pada Musim Hujan

\begin{tabular}{lcccc}
\hline \multicolumn{1}{c}{ Variabel } & Koefisien $\boldsymbol{\beta}$ & SE $(\boldsymbol{\beta})$ & $\mathbf{p}$ & OR (95\% IK) \\
\hline ISPA & 1,361 & 1,137 & 0,231 & $3,9(95 \%$ IK $=0,42-36,24)$ \\
Atopi & 18,638 & 23205,42 & 0,999 & - \\
Konstanta & 1,204 & - & - & - \\
\hline Akurasi: $83,7 \%$ & & & &
\end{tabular}


jalur $\mathrm{T}$ helper 2 (Th-2) sehingga sel mast dan basofil dirangsang untuk menghasilkan IL-4 dan IL-13. Selain itu, klon limfosit T abnormal akan melepaskan suatu mediator tertentu (circulating glomerulotoxic lymphokine) yang bersifat toksik terhadap membran basal glomerulus. Sitokin ini akan menyebabkan permeabilitas membran glomerulus meningkat, sehingga menyebabkan proteinuria. ${ }^{12}$ Mekanisme lain yang menerangkan terjadinya proteinuria adalah sitokin seperti vascular permeability factor (VPF), IL-4, dan IL 13 dapat menyebabkan hilangnya muatan negatif sialoglikoprotein dan proteoglikan heparan sulfat dalam dinding kapiler glomerulus, sehingga barier filtrasi glomerulus berkurang dan menyebabkan proteinuria. ${ }^{17}$

Penelitian Toyabe ${ }^{11}$ di Jepang yang merupakan negara dengan iklim empat musim menunjukkan kekambuhan penderita SNSS berhubungan dengan pola musim. Hingga saat ini penelitian yang mengaitkan antara pola musim dan kejadian kambuh di Indonesia (negara dengan iklim dua musim) pada penderita SN masih sedikit. Penelitian $\mathrm{Hafni}^{3}$ di Departemen Ilmu Kesehatan Anak RS Dr. Hasan Sadikin Bandung berdasarkan data sekunder (secara retrospektif) selama periode tahun 2000-2004 menunjukkan bahwa lebih banyak penderita SNSS yang dirawat pada periode Oktober-Maret dibandingkan dengan periode April-September. Penelitian kami diharapkan lebih baik, karena data diambil secara prospektif.

Menurut data Badan Meteorologi dan Geofisika Bandung, secara umum di wilayah Jawa Barat musim hujan terjadi pada periode Oktober-Maret, sedangkan musim kemarau terjadi pada periode April-September. ${ }^{15}$ Musim hujan daerah tropis ditandai dengan kelembaban udara yang tinggi dan suhu udara yang rendah. ${ }^{18}$

Penelitian ini juga mengikutsertakan faktor risiko lain (faktor penggangu), yaitu ISPA dan riwayat atopi. Pada analisis regresi logistik tidak terdapat hubungan ISPA dan riwayat atopi dengan kekambuhan. Dengan kata lain, hanya faktor musimlah yang berhubungan dengan kekambuhan. Pada penelitian ini riwayat atopi tidak ada hubungan dengan kejadian kambuh penderita SNSS. Hal ini kemungkinan dapat diterangkan berdasarkan penelitian Cheung dkk. ${ }^{19}$ yang menyatakan bahwa kejadian kambuh pada penderita SNSS yang diperantarai oleh upregulation IL-13 tampaknya menggambarkan aktivasi sejumlah mekanisme imunologis umum yang terjadi sesudah mendapatkan berbagai rangsangan luar, seperti infeksi virus saluran napas akut. Pengaruh langsung faktor atopi terhadap up-regulation IL-13 tersebut kurang berperan bila dibandingkan dengan rangsangan luar di atas. Kemungkinan lainnya disebabkan jumlah sampel yang sedikit, sehingga tidak dapat diambil kesimpulan. Walaupun demikian, faktor atopi hingga saat ini masih dianggap mempunyai hubungan dengan kekambuhan.

Penelitian ini menyimpulkan bahwa musim hujan merupakan faktor risiko terjadinya kambuh pada anak yang menderita SNSS.

\section{Daftar Pustaka}

1. Clark AG, Barratt TM. Steroid responsive nephrotic syndrome. Dalam: Barrat TM, Avner ED, Harmon WE, penyunting. Pediatric nephrology. Edisi ke-4. Baltimore: Lippincott Williams \& Wilkins; 1999. hlm. $731-47$

2. Wirya W. Gambaran klims sindrom nefrotik pada anak. Kumpulan Naskah Simposia KONIKA 1993. Semarang, 1993.

3. Hafni A. Perbandingan trombositosis pada anak sindrom nefrotik kambuh sering dan jarang (Tesis). Bandung: Bagian Ilmu Kesehatan Anak FKUP/RSHS; 2006.

4. Nash MA, Edelmann Jr CM, Bernstein $\mathrm{J}$, Barnett HL. Minimal change nephrotic syndrome, diffuse mesangeal hypercellularity, and focal glomerular sclerosis. Dalam: Edelmann Jr CM, Bernstein Jr CM, Meadow SR, penyunting. Pediatric kidney disease. Edisi ke-2. Boston: Little Brown \& Co; 1992. hlm. 1267-90.

5. ISKDC. Early identification of frequent relapse among children with minimal change nephrotic syndrome. J Pediatr. 1982;101(4):514-8.

6. Constantinescu AR, Shah HB, Foote EF, Pharm D, Weiss LS. Predicting first year relapses in children with nephrotic syndrome. Pediatrics. 2000;105:492-5.

7. Haycock GB. Steroid responsive nephrotic syndrome. Dalam: Postlethwaite RJ, penyunting. Clinical pediatric nephrology. Edisi ke-3. Oxford: Butterworth-Heineman; 2003. hlm. 253-9.

8. Meadow SR, Sarsfield JK, Scott DG, Rajah SM. Steroid responsive nephrotic syndrome and allergy: immunological studies. Arch Dis Child. 1981;56:517-24.

9. Haeffner A, Abbal M, Mytilineos J, Konrad TAI, Krammer I, Bouissou F, dkk. Oligotyping for HLA-DQA, -DQB, and -DPB in idiopathic nephrotic syndrome. Pediatr Nephrol. 1997;16:291-5.

10. Kabuki N, Okugawa T. Influence of age at onset on the outcome of steroid-sensitive nephrotic syndrome. Pediatr Nephrol. 1998; $12: 467-70$. 
11. Toyabe S. Circannual variation in the onset and relapse of steroid-sensitive nephrotic syndrome. Pediatr Nephrol. 2005;20:470-3.

12. Yap HK, Cheung W, Murugasu B, Keensim S, Serh CC, Jordan SC. Th1 and Th2 cytokine mRNA profiles in childhood nephrotic syndrome: evidence for increased IL-13 m RNA expression in relaps. J Am Soc Nephrol. 1999;10:529-36.

13. Glimcher LH, Murphy KM. Lineage commitment in the immune system: the $\mathrm{T}$ helper lymphocyte grows up. Genes Develop. 2000;14:1693-711.

14. Johansson SGO, Bieber T, Dahl R, Friedman PS, Lanier BQ, Lockey RF, dkk. Revised nomenclature for allergy for global use: report of the nomenclature review Committee of the World Allergy Organization, October 2003. J Allergy Clin Immunol. 2004;113:832-6.
15. Data Statistik Badan Meteorologi dan Geofisika Bandung tahun 2005-2006. Bandung: Badan Meteorologi dan Geofisika; 2006.

16. Kari JA, Sinnott P, Khan H, Trompeter RS, Snodgrass GJAI. Familial steroid responsive nephrotic syndrome and HLA antigens in Bengali children. Pediatr Nephrol. 2001;16:346-9.

17. Garin EH, West L, Zheng W. Interleukin-8 alters glomeruiar heparan sulfate glycosaminoglycan chain size and aharge in rats. Pediatr Nephrol. 2000;14(4):284-7.

18. Tyasyono B. Klimatologi. Edisi ke-2. Bandung: Penerbit ITB; 2004.

19. Cheung W, Ren EC, Chan SH, Gong WK, Yap HK. Increased HLAA* 11 in Chinese children with steroid responsive nephrotic syndrome. Pediatr Nephrol. 2002;17:212-6. 